\title{
Integrated Catalytic Burner/Micro-SOFC Design and Applications
}

\author{
Geoffrey A. TOMPSETT, ${ }^{a *}$ Caine FINNERTY, ${ }^{a}$ Kevin KENDALL, ${ }^{\mathrm{a}}$ \\ and Nigel M. SAMMES
}

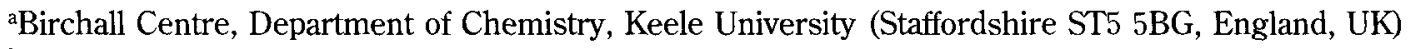 \\ ${ }^{b}$ Department of Materials and Process Engineering, University of Waikato (Private Bag 3105, Hamilton, New Zealand)
}

Received December 14, 1999 ; Accepted February 28, 2000

\begin{abstract}
In order to combine internal pre-reforming, heat for SOFC operation and clean combustion, a triple catalyst microSOFC unit was designed. The unit consisted of retrofitting a Camping Gaz ${ }^{\circledR}$ catalytic burner with a micro-SOFC stack and a Ru pre-reformer. The butane gas is jetted over the surface of the Pt honeycomb catalyst, where it is burnt to release heat. In order to utilise the gas for the co-generation of heat and electricity in the camping gas burner, the retrofitting of a 28 fuel cell stack above the combustion catalyst was investigated. In this case, the $\mathrm{Ni} / \mathrm{YSZ} / \mathrm{CeO} 2$ anode electrode layer is applied to the exterior of the electrolyte tube for the impinging fuel gas, and the dopedlanthanum manganite cathode layer is applied to the inside of the tubes. A pre-reforming catalyst comprising of $\mathrm{Ru}$ metal on Saffil ${ }^{\mathbb{R}}$ coamic wool, was used to partially reform the butane gas prior to the fuel cell, greatly improving the $\mathrm{OCV}$ and power output. The 28-cell stack micro-fuel cell system with the Ru pre-reformer was successfully retrofitted to the Camping $\mathrm{Gaz} z^{\circledR}$ burner and initial performance results were obtained.
\end{abstract}

Key Words : Micro-SOFC, Pre-reforming, Combustion Catalyst, Butane

\section{Introduction}

The high temperature operation of solid oxide fuel cells requires heating to temperatures of up to $1000^{\circ} \mathrm{C}$ for yttria stabilised electrolyte cells. This high temperature however allows the possibility of internal reforming of hydrocarbon fuels, to syn gas, for utilisation in the fuel cells. Hydrogen is the ideal fuel due to the fact that the product of combustion is water, however, hydrogen is not yet a widely accessible fuel source in most countries unlike many forms of hydrocarbon fuels either from fossil deposits or bio-mass sources.

Traditionally, micro tubular fuel cells as used by Kendall $e t a l .^{1,2)}$ are fabricated with the anode on the inside and cathode on the out side due to the fact that the fuelgas, for example $\mathrm{H}_{2}$, is passed through the inside while air is circulated on the outside to create the partial pressure difference. This has been successfully demonstrated with small Adelan ${ }^{\mathbb{B}}$ cells. $^{3,4)}$ and large stacks consisting of 200 and 1000 cells at Keele University. ${ }^{5,6)}$ and these micro-tubular SOFCs show excellent thermal shock properties.

The Camping Gaz ${ }^{(\mathbb{R})}$ company, have marketed a novel gas burner for outdoor cooking use, utilising a Pt coated honeycomb catalyst to combust the butane fuel instead of the typical flame burner system. Within the Camping $\mathrm{Gaz}{ }^{\circledR}$ burner, the butane gas is jetted over the surface of the honeycomb catalyst, where it is burnt to release heat. The aim is to utilise the butane gas that is jetted over the surface of the honeycomb catalyst, in the Camping gas burner for the co-generation of electricity using a micro-SOFC stack. With the ability to simultaneously provide heat for cooking and power for recharging torch batteries or a radio, for example, there are significant areas of application in the leisure industry.

In this paper, we outline the design of a co-generating device incorporating a catalytic burner and SOFC by the retrofitting a 28-fuel cell stack and pre-reformer to the burner system. This is in order to demonstrate the feasibility of such a system.

\section{Experimental Procedure}

\section{1 Fuel cell and catalyst components}

The compositions of the components and application procedures of the micro fuel cells is listed in Table 1, and the specific techniques are listed as follows:

(a) Electrolyte material

Micro-tubular SOFC electrolytes consisted of 8YSZ tubes (Viking chemicals) of $2.4 \mathrm{~mm}$ outside diameter, and $200 \mu \mathrm{m}$ wall thickness.

(b) Cathode layers

Two cathode layers were applied to the inside of the electrolyte tubes, using a syringe to draw the liquid up the inside of the tube to the desired height, held for 30 seconds, then releasing the pressure to allow the excess to drain.

(c) Anode layers

An initial layer of 8YSZ (Tosoh) was applied to the electrolyte tubes using an ink of methanol and PVB. Followed by drying in air and firing at $1450^{\circ} \mathrm{C}$ for $2 \mathrm{~h}$. This was a "key" layer for better adhesion of the anode layers to the exterior of the tubes.

Two anode layers were applied to the exterior of the 
Table 1 Micro-SOFC electrode fabrication materials and methods.

\begin{tabular}{|c|c|c|}
\hline Layer & $\begin{array}{l}\text { Composition } \\
\text { and synthesis }\end{array}$ & Application procedure \\
\hline $\begin{array}{l}1 \text { st } \text { Cathode layer } \\
-2 \text { coats }\end{array}$ & $\begin{array}{l}\text { La0.5 } \mathrm{Sr}_{0.5 \mathrm{MnO}} \text { (Seat- } \\
\text { tle Special Ceramics } \\
99.9 \% \text { pure) } \\
\mathrm{TZ10Y} \\
\mathrm{MeOH} \\
\text { Glycol trioerate } \\
\text { Ball milled for } 4 \mathrm{~h} \text { us- } \\
\text { ing 3YSZ milling media. }\end{array}$ & $\begin{array}{l}\text { Drawn into the tube } \\
\text { using a syringe. } \\
\text { Held for } 1 \mathrm{~min} \text { and } \\
\text { drip drying. } \\
\text { Repeated for second } \\
\text { coating. }\end{array}$ \\
\hline 2nd Cathode layer & $\begin{array}{l}\mathrm{La} 0.88 \mathrm{Sr} 0.12 \mathrm{MnO}_{3} \\
\text { (Merck, } 99.9 \% \text { pure) } \\
\text { Actone (AR) } \\
\text { KD } 1 \text { (Zencca) } \\
\text { Terpineol (pre-made) } \\
\text { Mill for } 5 \mathrm{~h} \text { followed } \\
\text { by addition of } 4 \mathrm{~g} \text { ter- } \\
\text { pineol and milling for } \\
5 \text { min. The evapora- } \\
\text { tion overnight to } \\
\text { form a vicious paste. }\end{array}$ & $\begin{array}{l}\text { Drawn into the tube } \\
\text { using a syringe fol- } \\
\text { lowed by blowing out } \\
\text { excess using com- } \\
\text { pressed air. } \\
\text { Air dried for } 10 \mathrm{~min} \text {. } \\
\text { Dried in oven at } 65^{\circ} \mathrm{C} \\
\text { for } 1 \mathrm{~h} \\
\text { Dried in oven at } \\
120^{\circ} \mathrm{C} \text { for } 1 \text { h. } \\
\text { Cut off blocked ends } \\
\text { of the tubes. } \\
\text { Dried for a further hr } \\
\text { at } 120^{\circ} \mathrm{C} \text {. }\end{array}$ \\
\hline "key" layer & $\begin{array}{l}\text { Calcined } 8 \mathrm{YSZ} \\
\mathrm{MeOH} \\
\mathrm{PVB} \text { and milled for } \\
4 \mathrm{~h} \\
\end{array}$ & $\begin{array}{l}\text { Painted on the elec- } \\
\text { trolyte tube air dried } \\
\text { and fired at } 1450^{\circ} \mathrm{C} \\
\text { for } 2 \mathrm{~h} \text {. }\end{array}$ \\
\hline 1st Anode layer & $\begin{array}{l}\text { Calcined } 8 \mathrm{YSZ} \\
\mathrm{NiO} \\
\mathrm{MeOH} \\
\text { 111-tricloroethene } \\
\text { Glycol trioerate } \\
\text { Mill for } 3 \mathrm{~h} \text { then add } \\
\text { a small amount of } \\
\text { PVB and mill for a } \\
\text { further } 3-5 \text { min. }\end{array}$ & $\begin{array}{l}\text { Painted on to tubes } \\
\text { and allowed to air } \\
\text { dry overnight. }\end{array}$ \\
\hline 2nd Anode layer & $\begin{array}{l}\text { Calcined } 8 \mathrm{YSZ} \\
\mathrm{NiO} \\
\mathrm{CeO}_{2} \\
\mathrm{MeOH} \\
\text { 111-tricloroethene } \\
\text { Glycol trioerate } \\
\text { Ball milled for } 3 \mathrm{~h} \text {. }\end{array}$ & $\begin{array}{l}\text { Painted on to the sur- } \\
\text { face and left to dry } \\
\text { overnight. }\end{array}$ \\
\hline Ru layer & $\begin{array}{l}\mathrm{RuCl}_{3} 5 \mathrm{wt} \% \text { in Etha- } \\
\text { nol }\end{array}$ & $\begin{array}{l}\text { Painted onto the anode } \\
\text { wires and calcined at } \\
600^{\circ} \mathrm{C} \text { for } 1 \mathrm{~h} \text {. }\end{array}$ \\
\hline
\end{tabular}

tubes by using a small paintbrush, with air drying between coatings. Two cells per tube were prepared at 2 $\mathrm{cm}$ in length, separated by $1 \mathrm{~cm}$.

(d) Sintering

Co-sintering of the electrodes to the electrolyte tubes was carried out using a muffle furnace. The firing procedure followed $1{ }^{\circ} \mathrm{C} / \mathrm{min}$ up to $500^{\circ} \mathrm{C}$ for binder burn out, then $300^{\circ} \mathrm{C} / \mathrm{min}$ up to $1300^{\circ} \mathrm{C}$ for $60 \mathrm{~min}$ dwell and finally cooling to room temperature.

(e) Current collectors

Anode contact wire consisted of silver wire of $0.25 \mathrm{~mm}$ diameter which was wound criss-cross along the anode length at a spacing of $c a .3 \mathrm{~mm}$ between windings. ${ }^{7}$ Cathode current collector wire consisted of braiding four $0.25 \mathrm{~mm}$ silver wires together followed by spiraling around a $1 \mathrm{~mm}$ diameter needle to form a tight coil. The coiled wire was then fed into the fuel cell tube jamming the coil inside to create a good contact with the cathode.

(f) Pre-reforming catalyst fabrication

$\mathrm{RuCl}_{3}$ solution ( $5 \mathrm{wt} \% \mathrm{Ru}$ in ethanol) $1 \mathrm{~mL}$ was applied to a circular sheet of Saffil ${ }^{\circledR}$ ceramic wool. A circular area of ruthenium catalyst of $50 \mathrm{~mm}$ diameter was created central to the Saffi ${ }^{\mathbb{R}}$ sheet. The solution was then dried in an oven at $50^{\circ} \mathrm{C}$ for $30 \mathrm{~min}$. On drying, the Saffil ${ }^{\mathbb{B}}$ sheet was rolled into a tube and placed in a screw seal stainless steal tube. The $\mathrm{RuCl}_{3}$ catalyst was reduced to $\mathrm{Ru}$ under hydrogen at $750^{\circ} \mathrm{C}$ for $1 \mathrm{~h}$ with $20 \mathrm{~mL} / \mathrm{min}$ gas flow rate. The pre-reformer catalyst on Saffil ${ }^{\circledR}$ was cemented (AUTOSTIC ${ }^{\mathbb{R}}$ ) to an insulating sheet of glass fibre board and placed on the underside of the unit lid.

\section{2 Construction of the co-generating gas burner}

As shown in Fig. 1, a stainless steel case was constructed to house the fuel cell stack. The case was retrofitted to the top of the catalytic burner in place of the burner lid. Ru catalyst on Saffil ${ }^{\mathbb{R}}$ was placed on the underside of the lid top. A $0.6 \mathrm{~W}$ fan was fitted to the side of the case and manifolded to the fuel cell tubes.

\section{3 Performance of the co-generating gas burner}

In order to ascertain the power output and performance of the fuel cell stack in the gas burner, first the cells were wired in parallel. The gas flow was turned to high and ignited using the piezoelectric igniter. The gas flow is adjusted using a control valve and is first passed through a pre-mix orifice where air and butane are

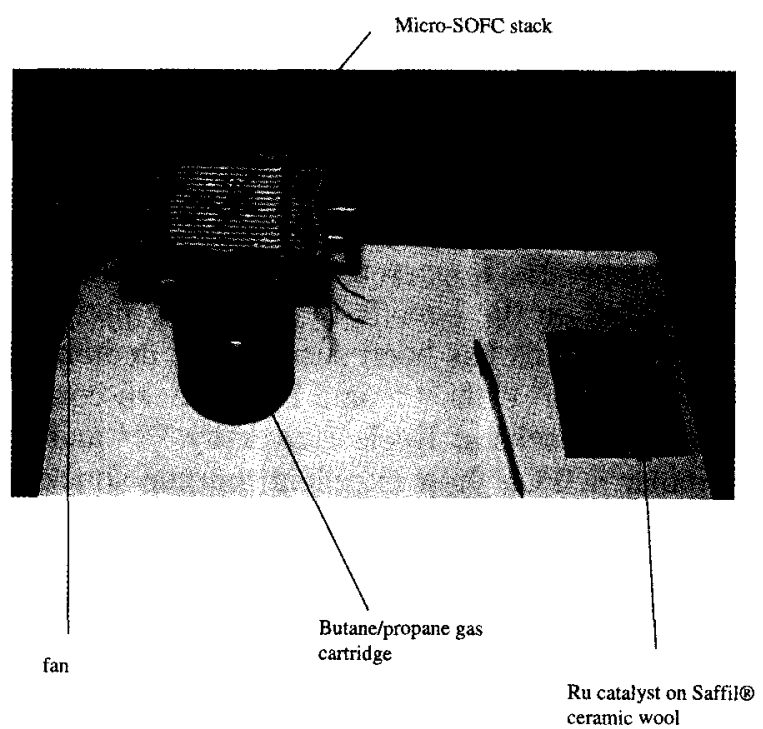

Fig. 1 Photograph of the triple layer catalyst-SOFC-catalyst system fitted to a Camping $\mathrm{Gaz}^{\mathbb{R}}$ burner. Note, the Ru catalyst is shown on the underside of the lid section (to the right) and only a single micro SOFC of shown fitted to the burner (to the left). 
mixed. The gas hits the bottom of the glass lid/prereforming catalyst and then impinges on the fuel cells then combustion catalyst where it is burnt. The gas took only a few seconds for the combustion catalyst to heat to a red glow, the heat from which heats the fuel cells and the pre-reforming catalyst. The voltage was monitored using a multimeter and the gas flow and presence of both the pre-reformer altered to observe their effect on the stack performance. A fan was also used to force air through the inside (cathode side) of the tubes manifolded as shown in Fig. 2. A small $1.5 \mathrm{~W}$ musical speaker was applied to the stack load to observe the power output.

\section{Results and Discussion}

The individual micro fuel cell tubes were initially reduced for $1 \mathrm{~h}$ at $800-900^{\circ} \mathrm{C}$ in $30 \mathrm{~mL} / \mathrm{min} \mathrm{H}_{2}$. Individual cell performances were recorded shown in Table 2, and the average cell performance was $c a .126 \mathrm{~mA}$ at $500 \mathrm{mV}$ for the two cells on a single tube wired in parallel. Greater cell performances have been obtained recently at $250 \mathrm{~mA}$ per cell at $500 \mathrm{mV}^{8}{ }^{3}$

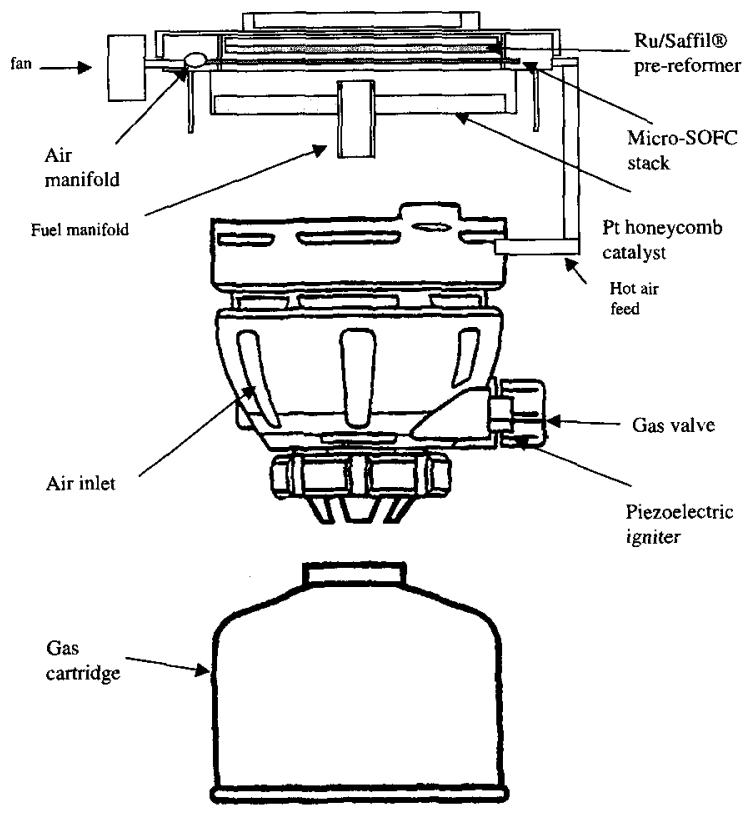

Fig. 2 Schematic of the Camping Gaz $\left.{ }^{(}\right)$burner components, showing the position of the micro-SOFC, the pre-reformer and combustion catalyst.

Table 2 List of typical individual cell OCV's, amperage and powder density outputs.

\begin{tabular}{c|c|c|c|c|c}
\hline Cell & $\begin{array}{c}\text { Anode/cathode } \\
\text { length } \\
(\mathrm{mm})\end{array}$ & $\begin{array}{c}\text { Temperature } \\
\left({ }^{\circ} \mathrm{C}\right)\end{array}$ & $\begin{array}{c}\text { OCV after } 1 \mathrm{~h} \\
\text { reduction at } \\
30 \mathrm{~mL} / \mathrm{min} \mathrm{H}_{2} \\
(\mathrm{mV})\end{array}$ & $\begin{array}{c}I(\mathrm{~mA}) \\
\text { at } 500 \mathrm{mV}\end{array}$ & $\begin{array}{c}\text { Power } \\
\text { density } \\
\left(\mathrm{mW} / \mathrm{cm}^{2}\right)\end{array}$ \\
\hline 1 & 30 & 900 & 1043 & 183 & 40 \\
2 & 40 & 900 & 1051 & 155 & 26 \\
3 & 30 & 900 & 1014 & 138 & 31 \\
4 & $2 \times 20$ & 850 & 1080 & 150 & 50 \\
5 & $2 \times 20$ & 880 & 1093 & 103 & 34 \\
\hline
\end{tabular}

Preliminary stack performance was studied as the component in the triple layer catalyst-micro SOFC - catalyst gas burner system. A thermocouple (K-type) was placed near the centre of the combustion catalyst radius under the fuel cell tubes. A multimeter was used to record the OCV of the fuel cell stack. It was found that a high gas flow was required to obtain temperature of $c a$. $800^{\circ} \mathrm{C}$ at the fuel cells, however, insufficient air flow through the inside of the tubes was created to produce sufficient power output. Further design modification and testing is in progress for this system to achieve greater power outputs. $^{9 \text { ' }}$

\section{Conclusions}

The initial design and construction of a co-generating camping gas burner incorporating a pre-reforming catalysis and a 28 cell micro-SOFC stack. The camping gas burner used which the Camping $\mathrm{Gaz}^{\mathrm{B}}$ company, have marketed a novel gas burner for outdoor cooking use, utilising a $\mathrm{Pt}$ coated honeycomb catalyst to combust the butane fuel instead of the typical flame burner system. A pre-reforming catalyst comprising of Ru metal on Saffil ${ }^{\circledR}$ coamic wool, was used to partially reform the butane gas prior to the fuel cell, greatly improving the OCV and power output. Initial performance results were obtained and it was shown that a co-generating system could be achieved using a micro-SOFC stack coupled with a prereformer in a catalytic gas burner, however, sufficient air flow is required on the cathode side of the fuel cell tubes. Improvements on design and fuel cell performance are in progress.

\section{Acknowledgements}

The authors would like to thank NEDO, Japan for the funding.

\section{References}

1) K. Kendall and G. Sales, 2nd International Conference on Ceramics in Energy Application, Institute of Energy, London, p.55 (1994).

2) I. P. Kilbride, J. Power Sources, 61, 167 (1996).

3) K. Kendall and M. Palin, J. Power Sources, 71, 268 (1998).

4) K. Kendall, Adelan Solid Oxide Fuel Cell brochure, Keele University (1998).

5) M. Prica, T. Alston, and K. Kendall, in Proceedings of the 5th International Symposium on SOFC (SOFCV) Aachen Germany, (Eds. U. Stimming, S. C. Singwal, H. Tagawa, and W. Lehnert), The Electrochemical Soc., p.619-625 (1997).

6) T. Alston, K. Kendall, M. Palin, M. Prica, and P. Windbank, J. Power Sources, 71, 271 (1998).

7) D. Williams, $\mathrm{PhD}$ thesis, Keele University [In preparation] (1998)

8) C. Finnerty, G. A. Tompsett, K. Kendall, and R. M. Ormerod, in 6th Grove Symposium, London, (1999).

9) C. Finnerty, G. Tompsett, K. Kendall, and N. M. Sammes, Nature, [Submitted] (1999). 